University for Business and Technology in Kosovo

UBT Knowledge Center

UBT International Conference

2017 UBT International Conference

Oct 28th, 4:30 PM - 6:00 PM

\title{
Physico-chemical properties of ginger oil, bee wax and black seeds
}

\author{
Qëndresa Istrefi \\ University of Prishtina \\ Rina Krasniqi \\ University of Prishtina \\ Arleta Rifati-Nixha \\ University of Prishtina, arleta.rifati@uni-pr.edu \\ Kaltrina Kastrati \\ University of Prishtina \\ Fatjonë Krasniqi \\ University of Prishtina
}

See next page for additional authors

Follow this and additional works at: https://knowledgecenter.ubt-uni.net/conference

Part of the Food Science Commons

\section{Recommended Citation}

Istrefi, Qëndresa; Krasniqi, Rina; Rifati-Nixha, Arleta; Kastrati, Kaltrina; Krasniqi, Fatjonë; and Përzhaku, Enver, "Physico-chemical properties of ginger oil, bee wax and black seeds" (2017). UBT International Conference. 169.

https://knowledgecenter.ubt-uni.net/conference/2017/all-events/169

This Event is brought to you for free and open access by the Publication and Journals at UBT Knowledge Center. It has been accepted for inclusion in UBT International Conference by an authorized administrator of UBT Knowledge Center. For more information, please contact knowledge.center@ubt-uni.net. 


\section{Presenter Information}

Qëndresa Istrefi, Rina Krasniqi, Arleta Rifati-Nixha, Kaltrina Kastrati, Fatjonë Krasniqi, and Enver Përzhaku 


\title{
Physico - Chemical Properties of Ginger Oil, Bee Wax and Black Seeds Oil
}

\author{
Qëndresa Istrefi ${ }^{1}$, Rina Krasniqi ${ }^{1}$, Arleta Rifati-Nixha ${ }^{1}$, Kaltrina Kastrati $^{1}$, Fatjonë \\ Krasniqi ${ }^{1}$, Enver Përzhaku ${ }^{1}$ \\ ${ }^{1}$ Chemistry Department, Faculty of Mathematical \& Natural Sciences, University \\ of Prishtina, Prishtina, 10000, Republic of Kosova \\ \{arleta.rifati-nixha, arleta.rifati@uni-pr.edu\}
}

\begin{abstract}
We investigated to emphasize the physico-chemical properties of these three compounds: ginger oil, bee wax and black seeds oil. After the determination we have come to the conclusion that for the ginger oil the values of the acid number, iodine number, soap and ester number have not changed from the standard values that are allowed. Therefore we conclude that this oil is healthy to be used in our daily diets. The bee wax after undergoing the necessary testing has showed that these chemical values, iodine number, soap and ester number have been deviated from the allowed standard values. However the acid number was the same as the allowed standard values. When it comes to black seeds oil experiments have given values within the allowed standards for the saponification and iodine number whereas for the acid and ester numbers the obtained values exceed the allowed values because the oil was expired.
\end{abstract}

Keywords: ginger oil, bee wax, black seeds oil, physico-chemical properties.

\section{INTRODUCTION}

The vegetable oils are varied. Almost from most plants, essential oils are obtained thanks to the latest technology. The vegetable oils that can be mentioned and can be found in the Albanian market are: black seedlings, hazelnuts, ginger, cardamom, caraway, watermelon, squash, tomato seed, grape seed, garlic, grapefruit, lime, pink, propolis, chamomile, cinnamon, aloe vera, mentes, eucalyptus, sweet almonds, etc.

Each of these oils has its specifics and is recommended in certain diseases. They have a wide use, are useful and are recommended to be used because they have very little side effects. One of the most important herbs is black seed oil.

Black seeds oil, ginger oil and bee wax are Hemani products. Hemani company is one of the world's most popular companies in the field of production and distribution of products of plant origin. Its mission is to get the product in the most natural way, without affecting its natural values.

According to its official website, all products are manufactured according to ISO 9001, 14001 and 18001 certification standards.

Production technology is in the cold pressure. According to this technology, the obtained product fully retains the health values and nutritional ingredients, because the processing is not subject to high temperatures that destroys a part of the components.

The products are $100 \%$ natural, contain no chemicals, no additives, no preservatives, no refined and no flavoring. 

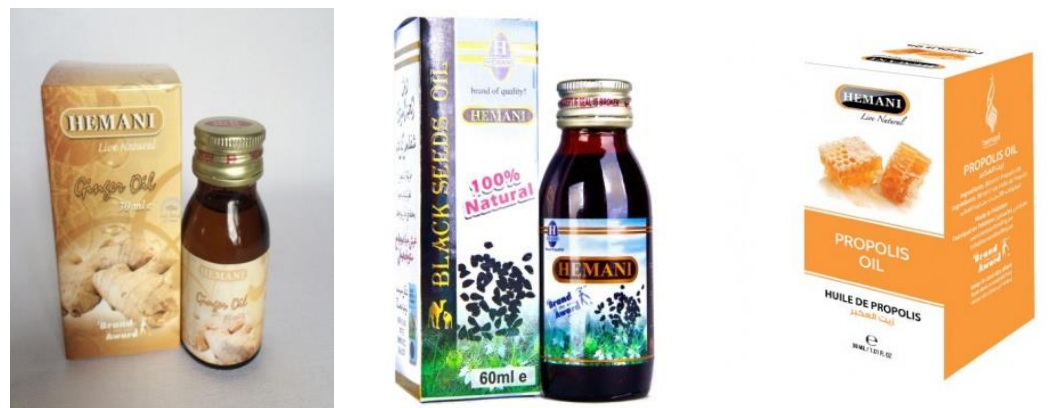

Figure 1. Ginger oil, black seeds oil and bee wax (propolis oil).

Ginger oil contains unstable oils, one of the most important of which is gingerol, which is useful for Reynaud syndrome (when the fingertips or legs become drowsy, cold and numb), serves as a stimulant for activity sexual, eliminates parasites, treats the ulcer and cleanses the spine. It is also useful in cases of dizziness, vomiting in pregnant women, memory strengthening, and lowering blood sugar levels. It has a yellow color and a heavy aroma.

Black seeds oil (Nigela Sativa) has a vast use of around 2,500 years and traces of its use have been found in ancient Greek and Egyptian civilizations. Today, black seed oil is considered a universal and extraordinary remedy for wellbeing.

Black seed oil has great effects, especially on diseases that stem from the weakness and inefficiency of the immune system.

From modern medicine it is claimed that this type of oil has curative properties for illnesses such as AIDS or tumor diseases. The black seed oil has a yellowish brown color and a heavy aroma.

Bee wax is an amazing substance produced by bees - female and this is commonly used to reduce cholesterol and relieve pain. It is also used for swelling and inflammation, and of course, it helps in the production of various forms of raw honey.

A study explored the antibacterial capabilities of the bee wax in the mouth, which apparently is a highly effective anti-microbial and found it to be significantly more powerful in eliminating certain microbes than calcium. Natural wax varies in color from almost white to light brown, but the perfect color is like the color of lemon, it has a wonderful and sweet flavor. It also has tastes like honey.

\section{METHODOLOGY}

We have used the titration method to determine the physical properties of our oils. The method is based on the digestion of our oils in the appropriate solvent and then titration with acids or bases depending on the properties being determined. Then the value was calculated based on the given formulas. After which we compared obtained experimental values with standard values. The boiling points are defined by the simple method of heating the oil to boiling point.

\section{Determination of the Iodine Number of Oils}

Reagents and tools:

- $\quad$ Oil or fat;

- Chloroform; 
- Hubel's Reagents;

- $\quad$ Potassium iodide, KI, 50 g / $500 \mathrm{~mL}$ distilled water;

- $\quad$ Sodium thiosulfate, $\mathrm{Na}_{2} \mathrm{~S}_{2} \mathrm{O}_{3}, 12.409 \mathrm{~g} / 500 \mathrm{~mL}$ of distilled water;

- $\quad$ Erlenmeyer of 250-300 ml with shingle cap, brews, pipettes;

- Starch $1 \%$.

Calculation of iodine number:

$$
\text { Iodine number }=\frac{(\mathrm{a}-\mathrm{b}) \mathrm{x} \mathrm{f} \times 0.01269 \times 100}{\mathrm{~A}}
$$

- $\quad \mathrm{a}-\mathrm{mL}$ spent on $\mathrm{Na}_{2} \mathrm{~S}_{2} \mathrm{O}_{3}$, for titration of the test assay;

- $\quad \mathrm{b}-\mathrm{mL}$ of spent $\mathrm{Na}_{2} \mathrm{~S}_{2} \mathrm{O}_{3}$, for titration of the test;

- $\mathrm{f}$ - the factor of $0.1 \mathrm{~mol} / \mathrm{L}$ of $\mathrm{Na}_{2} \mathrm{~S}_{2} \mathrm{O}_{3},(1.006)$;

- 0.01269 - the conversion coefficient of $\mathrm{mL}$ of spent $\mathrm{Na}_{2} \mathrm{~S}_{2} \mathrm{O}_{3}$, in grams for iodine. This means that $1 \mathrm{~mL}$ of $0.1 \mathrm{M}$ solution of $\mathrm{Na}_{2} \mathrm{~S}_{2} \mathrm{O}_{3}$, is equivalent to $0.01269 \mathrm{~g}$ iodine;

- $\quad$ A - the amount of oil measured;

- 100 - multiplies by 100 , to estimate how much iodine is associated with $100 \mathrm{~g}$ of fat.

\section{Determination of the Acidic Number of Oils}

\section{Reagents and tools:}

- $\quad$ Oils or fat;

- Neutral mixture in ratio 1: 1 (ethanol $\mathrm{C}_{2} \mathrm{H}_{5} \mathrm{OH}$ and ether $\mathrm{C}_{2} \mathrm{H}_{5} \mathrm{OC}_{2} \mathrm{H}_{5}$ );

- Phenolphthalein indicator, $\mathrm{C}_{20} \mathrm{H}_{14} \mathrm{O}_{4}, 100 \mathrm{~g} / \mathrm{L}$ (ethanol solution);

- Hydroxide Potassium, $0.1 \mathrm{~mol} / \mathrm{L}$;

- $\quad$ Erlenmeyer, Barrels, Pipettes, Scales, Funnels, Droppers.

Calculation of the acidic number:

$$
\text { Acidic number }=\frac{\mathrm{a} \times \mathrm{f} \times \mathrm{x} .61}{\mathrm{~A}}
$$

- $\quad \mathrm{a}-\mathrm{ml}$ spent on $0.1 \mathrm{~mol} / \mathrm{L} \mathrm{KOH}$ for titration of the test;

- $\mathrm{f}$ - the $\mathrm{KOH}$ solution factor $(0.98)$;

- 5.61- conversion coefficient of $\mathrm{mL}$ of $\mathrm{KOH}$ consumed in $\mathrm{mg} \mathrm{KOH}(1 \mathrm{~mL}$ of $0.1 \mathrm{~mol} / \mathrm{L} \mathrm{KOH}$ contains $5.6 \mathrm{mg} \mathrm{KOH}$ );

- A - the amount of oil to be measured. 


\section{Determination of the Saponification Number of Oils}

Reagents and tools:

- $\quad$ Oils or fat;

- Potassium hydroxide KOH $0.5 \mathrm{~mol} / \mathrm{L}$ (alcoholic solution at $95 \%$ ethanol);

- $0.5 \mathrm{~mol} / \mathrm{L}$ hydrochloric acid $\mathrm{HCl}(500 \mathrm{~mL})$;

- $\quad$ Phenolphthalein indicator, $\mathrm{C}_{20} \mathrm{H}_{14} \mathrm{O}_{4}, 100 \mathrm{~g} / \mathrm{L}$ (alcoholic tincture);

- Erlenmeyer $250 \mathrm{~mL}$, Barrel, Vertical Condenser, Water Bath, Pipette.

Calculation of saponification number:

$$
\text { Saponification number }=\frac{(a-b) \times f \times 28.05}{A}
$$

- $\quad \mathrm{a}-\mathrm{mL}$ of $0.5 \mathrm{M} \mathrm{HCl}$ for titration of the test assay;

- B-mL of spent $\mathrm{HCl}$ for titration of the test

- $\quad \mathrm{f}$ - factors of $\mathrm{HCl}(0.988)$;

- A - the amount of oil measured.

\section{Determination of the Esterification Number of Oils}

The esterification number is calculated by calculating the difference between the saponification number and the acidic number.

esterification number $=$ saponification number - acid number

\section{RESULTS AND DISCUSSION}

Table 4. Experimental data of boiling points.

\begin{tabular}{|l|l|}
\hline & BOILING POINTS \\
\hline BEE WAX & $107^{\circ} \mathrm{C}$ \\
\hline GINGER OIL & $221^{\circ} \mathrm{C}$ \\
\hline BLACK SEEDS OIL & $254^{\circ} \mathrm{C}$ \\
\hline
\end{tabular}

Table 5. Experimental data.

\begin{tabular}{|l|l|l|l|l|}
\hline & $\begin{array}{l}\text { IODINE } \\
\text { NUMBER }\end{array}$ & $\begin{array}{l}\text { ACIDIC } \\
\text { NUMBER }\end{array}$ & $\begin{array}{l}\text { SAPONIFICATION } \\
\text { NUMBER }\end{array}$ & $\begin{array}{l}\text { ESTERIFICATION } \\
\text { NUMBER }\end{array}$ \\
\hline BEE WAX & 292.346 & 1.467 & 80.37 & 78.903 \\
\hline GINGER OIL & 90.64 & 2.0159 & 162.12 & 160.1041 \\
\hline $\begin{array}{l}\text { BLACK SEEDS } \\
\text { OIL }\end{array}$ & 128.94 & 21.075 & 191.22 & 170.145 \\
\hline
\end{tabular}


Table 6. Standard data.

\begin{tabular}{|l|l|l|l|l|}
\hline & $\begin{array}{l}\text { IODINE } \\
\text { NUMBER }\end{array}$ & $\begin{array}{l}\text { ACIDIC } \\
\text { NUMBER }\end{array}$ & $\begin{array}{l}\text { SAPONIFICATION } \\
\text { NUMBER }\end{array}$ & $\begin{array}{l}\text { ESTERIFICATION } \\
\text { NUMBER }\end{array}$ \\
\hline BEE WAX & $120-185$ & $0.9-1.1$ & $188-194$ & 178.9 \\
\hline GINGER OIL & $87.6+/-0.1$ & $1.9+/-0.1$ & $150-190$ & $148.1-188.1$ \\
\hline $\begin{array}{l}\text { BLACK } \\
\text { SEEDS OIL }\end{array}$ & $110-125$ & 0.6 & $183-195$ & $182.4-194.4$ \\
\hline
\end{tabular}

In Table 2 are presented the experimental oil data after the analyzes are made while in Table 3 the data by literature. From this we can conclude that:

For bee wax, the values obtained by the experiments have given values within the allowed standards for the acid number, while the iodine number, saponification, and esterification number have deviation.

For ginger oil the values gained by the experiments have given values within the allowed standards for the acid, saponification and ester number, whereas the iodine number has deviation. For black seed oil the values gained by the experiments have given values within the allowed standards for the saponification and iodine number whereas for the acid and ester numbers the obtained values exceed the allowed values.

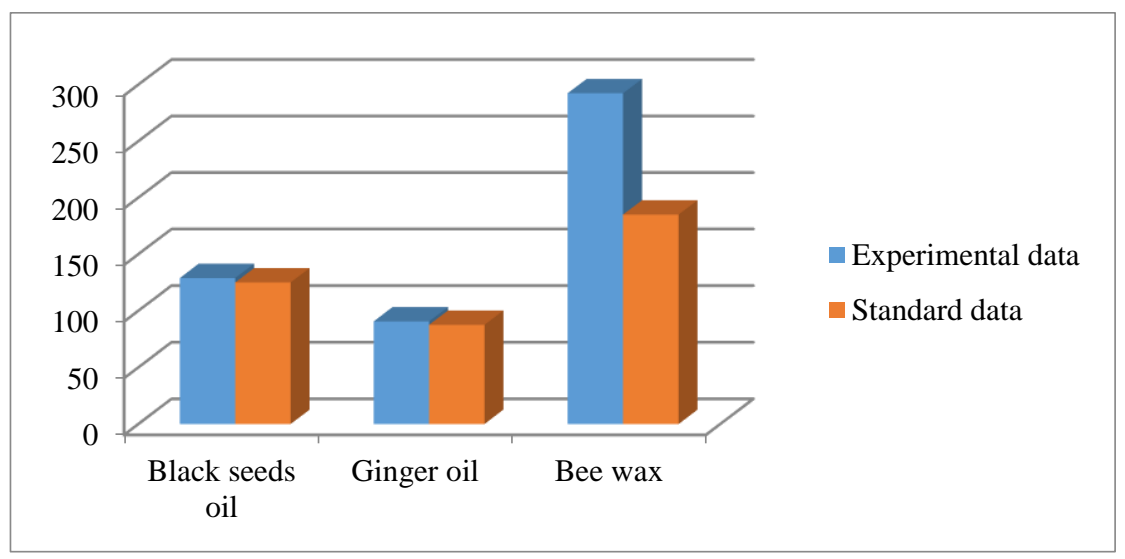

Figure 2. Experimental and standard data for iodine number. 


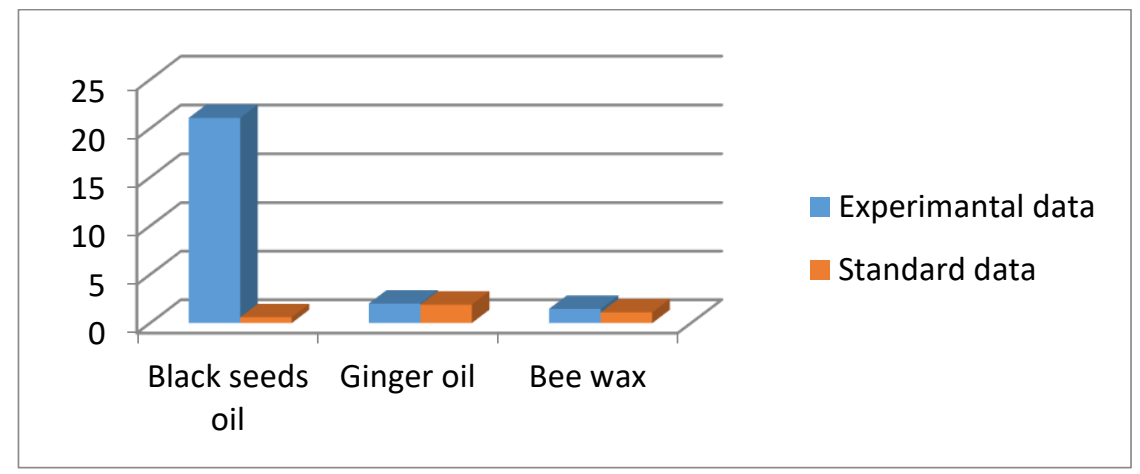

Figure 3. Experimental and standard data dor acidic number.

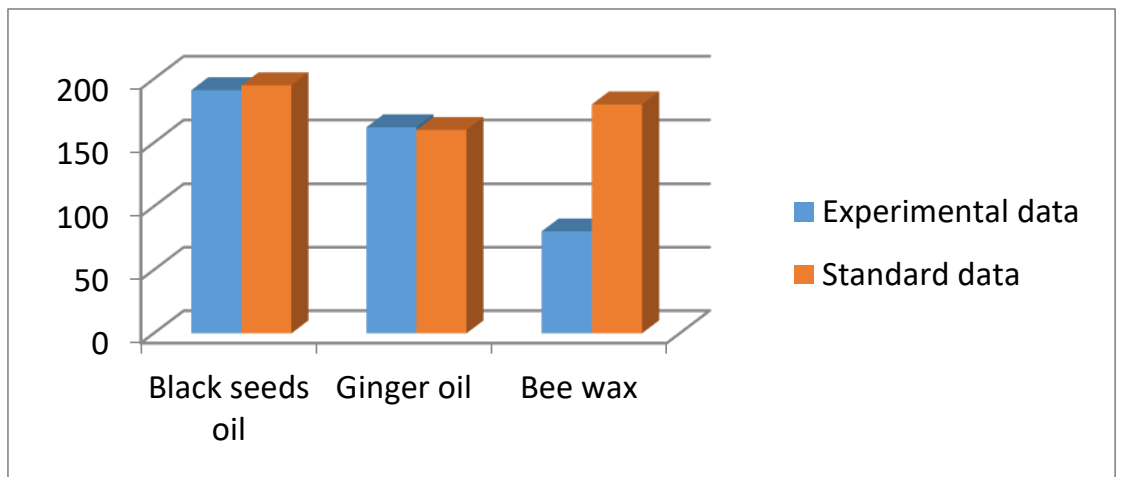

Figure 4. Experimental and standard data for saponification number.

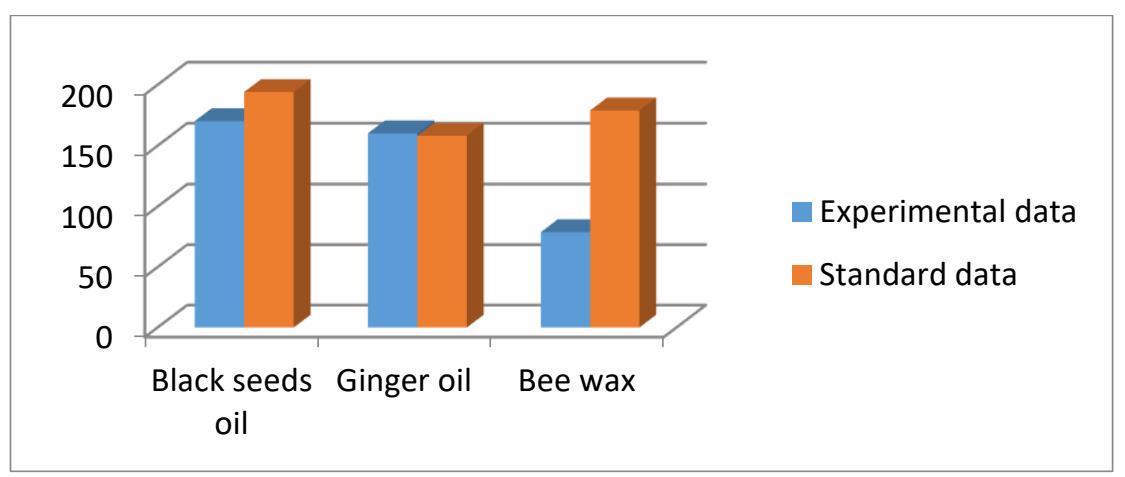

Figure 5. Experimental and standard data for esterification number. 


\section{REFERENCES}

1. Vance JE, Vance DE Biochemistry of Lipids, Lipoproteins and Membranes. Amsterdam: Elsevier. ISBN 978-0-444-51139-3. (2002)

2. Fats and Cholesterol: Out with the Bad, In with the Good - What Should You Eat? - The Nutrition Source". Harvard School of Public Health.

3. Maitland, Jr Jone,. W W Norton \& Co Inc (Np: Organic Chemistry ISBN 978-0-393-97378-5 (1998) p. 139.

4. Alfred Thomas"Fats and Fatty Oils". Ullmann's Encyclopedia of Industrial Chemistry. Weinheim: Wiley-VCH. doi:10.1002/14356007.a10 173 (2002). 